\title{
Non-small Cell Lung Cancer as a Chronic Disease - A Prospective Study from the Czech TULUNG Registry
}

\author{
MONIKA BRATOVA ${ }^{1,2}$, BARA KARLINOVA ${ }^{3}$, JANA SKRICKOVA ${ }^{1,2}$, MILOS PESEK $^{4,5}$, \\ VITEZSLAV KOLEK ${ }^{6,7}$, LEONA KOUBKOVA ${ }^{8,9}$, MICHAL HRNCIARIK ${ }^{10,11}$, JANA KREJCI $^{12}$, \\ MAGDA BARINOVA ${ }^{13}$, LIBOR HAVEL $^{14}$, IVONA GRYGARKOVA ${ }^{15}$ and KRISTIAN BRAT ${ }^{1,2}$ \\ ${ }^{1}$ Department of Respiratory Diseases, University Hospital Brno, Brno, Czech Republic; \\ ${ }^{2}$ Faculty of Medicine, Masaryk University, Brno, Czech Republic; \\ ${ }^{3}$ Faculty of Economics and Administration, Masaryk University, Brno, Czech Republic; \\ ${ }^{4}$ Department of Pneumology, University Hospital Pilsen, Pilsen, Czech Republic; \\ ${ }^{5}$ Faculty of Medicine, Charles University in Prague, Pilsen, Czech Republic; \\ ${ }^{6}$ Department of Respiratory Medicine, University Hospital Olomouc, Olomouc, Czech Republic; \\ ${ }^{7}$ Palacky University, Olomouc, Czech Republic; \\ ${ }^{8}$ Department of Pneumology, University Hospital Motol, Prague, Czech Republic; \\ ${ }^{9}$ Second Faculty of Medicine, Charles University in Prague, Prague, Czech Republic; \\ ${ }^{10}$ Department of Pneumology, University Hospital Hradec Kralove, Hradec Kralove, Czech Republic; \\ ${ }^{11}$ Faculty of Medicine, Charles University in Prague, Hradec Kralove, Czech Republic; \\ ${ }^{12}$ Department of Pneumology and Thoracic Surgery, Bulovka Hospital, Prague, Czech Republic; \\ ${ }^{13}$ Institute of Biostatistics and Analyses, Ltd., Brno, Czech Republic; \\ ${ }^{14}$ Department of Respiratory Medicine, Thomayer Hospital, Prague, Czech Republic; \\ ${ }^{15}$ Department of Respiratory Diseases, Prostejov Hospital, Prostejov, Czech Republic
}

\begin{abstract}
Aim: To compare survival outcomes in patients with non-small cell lung cancer (NSCLC) treated with modern-era drugs (antifolates, antiangiogenics, tyrosine kinase and anaplastic lymphoma kinase inhibitors, immunotherapy) with treatment initiation in 2011-12 and 2015-16, respectively. Patients and Methods: Prospective data from Czech TULUNG Registry (960 patients from 2011-12 and 512 patients from 2015-16) were analyzed. Kaplan-Meier analysis was used to estimate overall survival (OS) and progression-free survival (PFS); Cox proportional hazards model to assess factors associated with 2-year survival. Results: Survival at 2 years was more frequent in cohort 2015-16 compared to cohort 2011$12(43.2 \%$ vs. $24 \%$ for adenocarcinoma; $p<0.001$ and $28.7 \%$ vs. $11.8 \%$ for squamous-cell lung carcinoma; $p=0.002$ ).
\end{abstract}

This article is freely accessible online.

Correspondence to: Kristian Brat, MD, Ph.D., Department of Respiratory Diseases, University Hospital Brno and Faculty of Medicine, Masaryk University, Jihlavska 20, 62500 Brno, Czech Republic. E-mail: kristian.brat@seznam.cz

Key Words: Non-small cell lung cancer, 2-year survival, modernera treatment, personalized treatment, chronic disease.
Assignment to cohort 2015-16 and treatment multilinearity (two or more lines in sequence) were associated with higher probability of 2-year survival (hazard ratio $=0.666$ and hazard ratio $=0.597 ; p<0.001$ ). Comparison of 2-year survivors from both cohorts showed no differences. Conclusion: Survival at 2 years probability in stage IIIB-IV NSCLC doubled between 2011-12 and 2015-16; advanced-stage NSCLC may be considered a chronic disease in a large proportion of patients.

With the exception of non-melanoma skin carcinoma, lung cancer is the leading form of cancer worldwide with alarming incidence and mortality. In 2018, as many as $2,093,876$ new cases were reported worldwide (1) and Iung cancer claimed 1,761,007 lives (2). Incidence in Central and Eastern Europe in 2018 was 149,013 cases, while mortality was 131,369 (2). In the Czech Republic, 6,782 new cases of lung cancer were reported in 2016 (3).

The most widely used anticancer agents in the treatment of non-small cell lung cancer (NSCLC) include various chemotherapeutic drugs as well as newer agents [antifolates, antiangiogenic drugs, tyrosine kinase inhibitors (TKIs), anaplastic lymphoma kinase (ALK) inhibitors and immunotherapy]. The newer drugs facilitate a more targeted and personalized treatment. Some of the newly synthesized agents reach even higher progression-free survival (PFS) 
within their therapeutic use than is the overall survival (OS) for platinum derivatives ( $\mathrm{OS}=8-10$ months), e.g. dacomitinib in patients with endothelial growth factor receptor (EGFR) gene mutation (PFS=14 months), osimertinib in T790M $E G F R$-positive (PFS=18.9 months) or alectinib in $A L K$ positive disease ( $\mathrm{PFS}=34.8$ months) $(4,5)$. This is a major improvement in OS compared to patients with untreated NSCLC, where the disease course was usually very rapid and OS was only 4-6 months (1). The latest treatment progress means that a certain proportion of patients with NSCLC may benefit substantially and this may result in onset of disease chronicity.

There is no universal definition of a chronic disease in terms of specific diagnosis and disease duration. The World Health Organisation (WHO) defines a chronic disease as a disease of long duration and generally slow progression (6). The WHO recognizes four main types of chronic disease: cardiovascular diseases, chronic respiratory diseases, cancer (in general), and diabetes (7). In daily clinical practice, a disease is considered as chronic usually when it has slow progression and at least several months of duration (7). Using this definition, lung cancer may be considered a chronic disease only under certain circumstances (7).

The aim of our study was to compare 2-year survival, OS and PFS of patients with stage IIIB-IV NSCLC from the Czech TULUNG Registry treated with modern-era treatments in two different time periods (2011-2012 and 2015-2016). Our secondary aim was to analyze factors associated with 2-year survival and to compare specific features of modern-era treatments (anticancer agents used, treatment outcomes and side-effects assessed) during both time periods. Accordingly, we hypothesized that the probability of 2-year survival in patients with NSCLC might have increased significantly during the last few years, following the introduction of new drugs. Survival at 2 years was arbitrarily chosen as a measure/marker of chronic disease course. This was based on previous knowledge, i.e. that OS in untreated and in chemotherapy-treated patients with NSCLC was reported as 4-6 months and 8-10 months, respectively (1). Thus, we considered 2 -year survival as a marker of a distinctive therapeutic benefit.

\section{Patients and Methods}

For the purpose of this study, we analyzed data from the TULUNG registry (a joint registry of the Czech Pneumological Society, Czech Society for Oncology and Institute of Biostatistics and Analyses, Ltd.) of patients with NSCLC receiving modern-era anticancer treatments. Briefly, the Czech TULUNG clinical registry is a prospective multicenter database of patients with advanced-stage (IIIB-IV) NSCLC treated with antifolates, biological agents and/or immunotherapy. Patient recruitment (provided in 11 tertiary- or university-type healthcare centers in the Czech Republic) was initiated on April 1 ${ }^{\text {st }}$ 2011. Written informed consent was signed by each patient participating in the research. Participation in the study was not mandatory and had no relation to specific treatment accessibility for patients. For each patient, the following anonymized data were recorded: demographic data (age, sex, height, weight, body mass index, performance status), patient history data (smoking status, comorbidities), cancer histology, disease stage at the time of diagnosis (seventh TNM classification) (8), results of molecular genetic testing, specific treatments use (including dosage, adverse effects record, cause of treatment discontinuation), radiotherapy or surgical treatment, and survival data. The data are collected continuously and actualized regularly at least twice a year.

In order to compare differences in probability of 2-year survival during the years 2011-12 and 2015-16 (as well as for comparison of PFS and OS), data of two cohorts of patients with NSCLC from two distinct time periods were analyzed. Cohort 1 included patients with individualized treatment initiated between April $1^{\text {st }} 2011$ and December $31^{\text {st }} 2012$, while cohort 2 included patients with treatment initiated between July $1^{\text {st }} 2015$ to June $30^{\text {th }} 2016$. PFS, OS and 2year survival were measured from the initiation of first line of modern-era treatment (i.e. at patient entry in the TULUNG registry).

Statistical analyses. Basic characteristics of both cohorts were described by standard descriptive statistics. The data are presented as mean (median) $\pm \mathrm{SD}$. Chi-squared test and Fisher exact test were used for comparison of variables between both cohorts. KaplanMeier (KM) survival analysis was used to estimate 2-year survival, OS and PFS, and log-rank test was used to assess significance of differences from the KM graphs of both cohorts. Multivariate Cox proportional hazard model was used to assess factors associated with 2-year survival. As a level of acceptable statistical significance, a value $p<0.05$ was used.

Ethics. The study was approved by the Institutional Ethics Committees of all participating centers of the TULUNG registry [University Hospital Brno, University Hospital Pilsen, University Hospital Olomouc, University Hospital Hradec Kralove, University Hospital Motol (Prague), University Hospital Prague-Bulovka, Thomayer Hospital (Prague) and VFN (Prague)]. This study was approved by the Ethics Committee of the University Hospital Hradec Kralove on May $11^{\text {th }}, 2018$, reference number: 201805 I134R.

\section{Results}

Cohort 1 included a total of 960 patients, while cohort 2 consisted of 512 patients with NSCLC. In cohort 1 , the mean age of the patients was 63.7 years and $58.9 \%$ were men; in cohort 2, mean age was 64.5 years; $55.9 \%$ were men (Table I). In both cohorts, patients with adenocarcinoma and squamous-cell lung cancer (SCC) were most abundant, while patients with other histological types of NSCLC were less frequent/rare. Due to the low number of patients with other types, these subgroups were not eligible for a detailed statistical analysis and were excluded from further analyses. In consequence, only data of adenocarcinoma and SCC patients were further analyzed, each separately. Cohort 1 included 599 patients with adenocarcinoma (62.4\%) and 243 (25.3\%) with SCC; cohort 2 included 388 (75.6\%) with adenocarcinoma and $86(16.8 \%)$ with SCC, respectively. 
Table I. Basic characteristics of the complete cohorts 1 (years 2011-12) and 2 (years 2015-16).

\begin{tabular}{|c|c|c|c|c|}
\hline Parameter & Parameter & Cohort $1(\mathrm{~N}=960)$ & Cohort $2(\mathrm{~N}=512)$ & $p$-Value \\
\hline \multirow[t]{3}{*}{ Survival } & Median OS (95\% CI), months & $9.7(8.8 ; 10.9)$ & $16.9(14.6 ; 20.0)$ & $<0.001$ \\
\hline & 2-Year survival $(95 \% \mathrm{CI}), \%$ & $21.3(18.5 ; 24.5)$ & $38.7(33.6 ; 44.6)$ & $<0.001$ \\
\hline & Median PFS (95\% CI), months & $3.5(3.2 ; 4.0)$ & $6.2(5.4 ; 6.9)$ & $<0.001$ \\
\hline Age, years & Median (min-max) & $64.3(25 ; 87)$ & $65.9(33 ; 90)$ & 0.048 \\
\hline \multirow[t]{2}{*}{ Gender, n (\%) } & Male & $563(58.6 \%)$ & $294(57.4 \%)$ & 0.673 \\
\hline & Female & $397(41.4 \%)$ & $218(42.6 \%)$ & \\
\hline \multirow[t]{2}{*}{ Smoking history, n (\%) } & Past or current smoker & $743(77.4 \%)$ & $395(77.2 \%)$ & 0.847 \\
\hline & Non-smoker & $217(22.6 \%)$ & $117(22.8 \%)$ & \\
\hline Weight, kg & Median (min-max) & $76(39 ; 143)$ & $76(39 ; 137)$ & 0.498 \\
\hline Height, $\mathrm{cm}$ & Median (min-max) & $170(144 ; 198)$ & $170(145 ; 193)$ & 0.736 \\
\hline $\mathrm{BMI}, \mathrm{kg} / \mathrm{m}^{2}$ & Median (min-max) & $26.1(15 ; 44)$ & $26.2(15 ; 47)$ & 0.532 \\
\hline \multirow[t]{6}{*}{ Histology, n (\%) } & Adenocarcinoma & $599(62.4 \%)$ & $388(75.6 \%)$ & \\
\hline & Squamous & $243(25.3 \%)$ & $86(16.8 \%)$ & \\
\hline & Adenosquamous & $11(1.1 \%)$ & $3(0.6 \%)$ & \\
\hline & Non-specified NSCLC & $65(6.8 \%)$ & $17(3.4 \%)$ & \\
\hline & Large-cell carcinoma & $22(2.3 \%)$ & $1(0.2 \%)$ & \\
\hline & Other & $20(2.1 \%)$ & $17(3.4 \%)$ & \\
\hline
\end{tabular}

OS: Overall survival; PFS: progression-free survival; CI: confidence interval; BMI: body mass index; NSCLC: non-small cell lung cancer.

Comparison of demographic data, smoking history, comorbidities, disease stages, EGFR and $A L K$ driver mutations, and personalized treatments in both cohorts is presented in Table II for patients with adenocarcinoma and Table III for those with SCC.

Briefly, in those with adenocarcinoma, no major differences in demographic characteristics were observed between the two cohorts. There was a significant difference between cohorts in prevalence of hypertension $(38.9 \%$ in cohort $1 \mathrm{vs} .27 .8 \%$ in cohort $2 ; p<0.001)$ and thromboembolism $(11.2 \%$ vs. $5.4 \%$; $p=0.003)$, in cohort 1 , more patients were pretreated with conventional chemotherapy $(38.1 \%$ vs. $18 \% ; p<0.001)$ and there were differences in use of modern-era treatments between the cohorts (Table II). Median OS was significantly longer in cohort 2 compared to cohort 1 (19.7 vs. 10.6 months; $p<0.001)$, as well as PFS (7.1 vs. 4 months). Survival at 2 years was significantly higher in cohort 2 (43.2\% vs. 24\%; $p<0.001$ ) (Table II).

Similarly, in patients with SCC, no differences in demographic characteristics were observed. In cohort 1, hypertension was significantly more prevalent (37\%) compared to cohort $2(23.3 \%)(p=0.028)$. Median OS was significantly longer in cohort 2 compared to cohort 1 (12 vs. 7.3 months; $p=0.002)$, as was PFS (4.9 vs. 3 months; $p<0.001)$. Similarly to the adenocarcinoma cohort, 2-year survival of patients with SCC was significantly higher in cohort 2 compared to cohort 1 (28.7\% vs. $11.8 \% ; p=0.002)$ (Table III).

In patients with adenocarcinoma, the Cox proportional hazards model showed only assignment to cohort 2 and treatment multilinearity (i.e. two or more lines of anticancer treatment used in a sequence) as factors independently associated with significantly higher probability of 2-year survival [hazard ratio $(\mathrm{HR})=0.666$ and $\mathrm{HR}=0.597-0.299$, respectively; both $p<0.001$ ] (Table IV). In patients with SCC, only the occurrence of side-effects during anticancer treatment was associated with higher probability of 2-year survival $(\mathrm{HR}=0.714 ; p=0.017)$. There was also a trend towards reduced hazard in patients assigned to cohort 2 $(\mathrm{HR}=0.74 ; p=0.166)$ (Table IV).

Comparison of 2-year adenocarcinoma survivors from cohorts 1 and 2 showed no differences in terms of demographic characteristics, initial disease stage, comorbidities, mutation frequency, or total number of treatment lines used. The only differences observed were in specific treatments use in both cohorts, which reflected the time course of the introduction of new anticancer drugs during those years (Table V). The same pattern was observed in patients with SCC from cohorts 1 and 2 who survived 2 years or more (Table VI).

\section{Discussion}

The main finding of our study was that the proportion of patients with NSCLC surviving 2 years from specific treatment initiation doubled between 2011-12 and 2015-16. This observation was more pronounced in patients with adenocarcinoma, but was clearly expressed also in patients with SCC. The overall probability of 2-year survival in our cohorts of patients with NSCLC receiving modern-era treatments increased from 20 to $36 \%$ (in those with adenocarcinoma from $24 \%$ to $43.2 \%$ ) between $2011-12$ and 2015-16. 
in vivo $34: 369-379(2020)$

Table II. Comparison of patients with adenocarcinoma from cohort 1 (2011-12) and cohort 2 (2015-16).

\begin{tabular}{|c|c|c|c|c|}
\hline Parameter & Parameter & Cohort $1(\mathrm{~N}=599)$ & Cohort $2(\mathrm{~N}=388)$ & $p$-Value \\
\hline \multirow[t]{3}{*}{ Survival } & Median OS (95\% CI), months & $10.6(9.3-11.8)$ & $19.7(17.0-24.9)$ & 0.001 \\
\hline & 2-Year survival (95\% CI),\% & $24.0(20.5-28.1)$ & $43.2(37.2-50.1)$ & 0.001 \\
\hline & Median PFS (95\% CI), months & $4.0(3.3-4.6)$ & $7.1(6.5-8.3)$ & 0.001 \\
\hline Age, years & Median (min-max) & $63.6(62.8-64.4)$ & $64.3(63.4-65.3)$ & 0.239 \\
\hline Gender, n (\%) & $\operatorname{Men}(\mathrm{n} ; \%)$ & $318(53.1 \%)$ & $196(50.5 \%)$ & 0.486 \\
\hline Smoking history, n (\%) & Past or current smoker & $431(72.0 \%)$ & $274(70.6 \%)$ & 0.703 \\
\hline BMI, $\mathrm{kg} / \mathrm{m}^{2}$ & Median (min-max) & $25.9(16-44)$ & $26.2(15-47)$ & 0.725 \\
\hline \multirow[t]{3}{*}{ Performance status, n (\%) } & 0 & $127(21.3 \%)$ & $86(22.2 \%)$ & 0.795 \\
\hline & 1 & $428(71.8 \%)$ & $292(75.5 \%)$ & 0.236 \\
\hline & 2 & $41(6.9 \%)$ & $9(2.3 \%)$ & 0.002 \\
\hline \multirow[t]{7}{*}{ Clinical stage at diagnosis* $(\%)$} & IA & $15(2.5 \%)$ & $13(3.4 \%)$ & 0.564 \\
\hline & IB & $13(2.2 \%)$ & $9(2.3 \%)$ & $>0.99$ \\
\hline & IIA & $13(2.2 \%)$ & $11(2.8 \%)$ & 0.658 \\
\hline & IIB & $8(1 \%)$ & $10(2.6 \%)$ & 0.241 \\
\hline & IIIA & $43(7.2 \%)$ & $25(6.5 \%)$ & 0.741 \\
\hline & IIIB & $101(17.0 \%)$ & $45(11.7 \%)$ & 0.027 \\
\hline & IV & $406(67.6 \%)$ & $275(70.7 \%)$ & 0.322 \\
\hline \multirow[t]{3}{*}{ Mutation status, n (\%) } & Total & 360 & 335 & \\
\hline & $E G F R$-positive & $85(23.6 \%)$ & $82(24.5 \%)$ & 0.858 \\
\hline & $A L K$-positive & $6(1.7 \%)$ & $15(4.5 \%)$ & 0.052 \\
\hline \multirow[t]{3}{*}{ Comorbidities, n (\%) } & Hypertension & $233(38.9 \%)$ & $108(27.8 \%)$ & 0.001 \\
\hline & Thromboembolism & $67(11.2 \%)$ & $21(5.4 \%)$ & 0.003 \\
\hline & Tumor multiplicity & $56(9.3 \%)$ & $26(6.7 \%)$ & 0.176 \\
\hline \multirow[t]{3}{*}{ Number of treatment lines, $\mathrm{n}(\%)$} & 1 & $331(55.3 \%)$ & $226(58.2 \%)$ & 0.390 \\
\hline & 2 & $244(40.7 \%)$ & $115(29.6 \%)$ & 0.001 \\
\hline & $\geq 3$ & $24(4.0 \%)$ & $47(12.1 \%)$ & 0.001 \\
\hline Chemotherapy pre-treatment, $\mathrm{n}(\%)$ & Yes & $228(38.1 \%)$ & $70(18.0 \%)$ & 0.001 \\
\hline \multirow[t]{7}{*}{ Modern treatment, n (\%) } & Afatinib & $0(0 \%)$ & $38(9.7 \%)$ & 0.001 \\
\hline & Bevacizumab & $23(3.8 \%)$ & $106(27.3 \%)$ & 0.001 \\
\hline & Crizotinib & $5(0.8 \%)$ & $12(3.1 \%)$ & 0.019 \\
\hline & Erlotinib & $369(61.6 \%)$ & $92(23.7 \%)$ & 0.001 \\
\hline & Gefitinib & $54(9.0 \%)$ & $28(7.2 \%)$ & 0.324 \\
\hline & Nivolumab & $7(1.1 \%)$ & $28(7.2 \%)$ & 0.001 \\
\hline & Pemetrexed & $435(72.6 \%)$ & $290(74.7 \%)$ & $>0.99$ \\
\hline Radiotherapy, n (\%) & Yes & $89(14.9 \%)$ & $58(14.9 \%)$ & $>0.99$ \\
\hline Lung surgery $(\%)$ & Yes & $90(15.0 \%)$ & $67(17.3 \%)$ & 0.394 \\
\hline Side-effects, n (\%) & Yes & $255(42.6 \%)$ & $85(21.9 \%)$ & $<0.001$ \\
\hline \multirow{5}{*}{ Grade of side-effect, n (\%) } & Total & 511 & 166 & \\
\hline & 1 & $154(30.1 \%)$ & $21(12.7 \%)$ & 0.001 \\
\hline & 2 & $196(38.4 \%)$ & $64(38.6 \%)$ & $>0.99$ \\
\hline & 3 & $123(24.1 \%)$ & $69(41.6 \%)$ & 0.001 \\
\hline & 4 & $38(7.4 \%)$ & $12(7.2 \%)$ & $>0.99$ \\
\hline \multirow[t]{6}{*}{ Side effect, $\mathrm{n}(\%)$} & Dermatitis & $160(30.5 \%)$ & $14(8.4 \%)$ & 0.001 \\
\hline & Neutropenia & $62(11.8 \%)$ & $31(18.7 \%)$ & 0.033 \\
\hline & Anemia & $47(9.0 \%)$ & $13(7.8 \%)$ & 0.773 \\
\hline & Thrombocytopenia & $24(4.6 \%)$ & $15(9.0 \%)$ & 0.048 \\
\hline & Liver enzyme elevation & $10(1.9 \%)$ & $0(0 \%)$ & 0.156 \\
\hline & Other & $208(40.7 \%)$ & $93(56.0 \%)$ & 0.003 \\
\hline \multirow[t]{3}{*}{ Radiotherapy and, n (\%) } & Total & 89 & 58 & \\
\hline & 1 Treatment line & $54(60.7 \%)$ & $43(74.1 \%)$ & 0.132 \\
\hline & $\geq 2$ Treatment lines & $35(39.3 \%)$ & $15(25.9 \%)$ & 0.132 \\
\hline \multirow{2}{*}{$E G F R$-positive, n (\%) } & $\mathrm{N}$ & 85 & 82 & \\
\hline & $\geq 2$ Treatment lines & $37(43.5 \%)$ & $23(28.0 \%)$ & 0.054 \\
\hline
\end{tabular}

OS: Overall survival; PFS: progression-free survival; CI: confidence interval; BMI: body mass index; EGFR: endothelial-growth factor receptor gene mutation; $A L K$ : anaplastic lymphoma kinase gene mutation. ${ }^{*}$ Seventh edition of TNM classification of malignant tumors (8). 
Table III. Comparison of patients with squamous-cell lung cancer from cohort 1 (years 2011-12) and cohort 2 (years 2015-16).

\begin{tabular}{|c|c|c|c|c|}
\hline Parameter & Parameter & Cohort $1(\mathrm{~N}=243)$ & Cohort $2(\mathrm{~N}=86)$ & $p$-Value \\
\hline \multirow[t]{3}{*}{ Survival } & Median OS (95\% CI), months & $7.3(6.7-9.5)$ & $12.0(9.2-16.5)$ & 0.002 \\
\hline & 2-Year $(95 \% \mathrm{CI}), \%$ & $11.8(7.6-18.2)$ & $28.7(18.5-44.5)$ & $<0.001$ \\
\hline & Median PFS (95\% CI), months & $3.0(2.4-3.5)$ & $4.9(4.0-5.7)$ & \\
\hline Age, years & Median (min-max) & $64.3(28-87)$ & $66.2(45-87)$ & 0.157 \\
\hline Gender, n (\%) & Male & $181(74.5 \%)$ & $66(76.7 \%)$ & 0.786 \\
\hline Smoking history, n (\%) & Past or current smoker & $218(89.7 \%)$ & $84(97.7 \%)$ & 0.037 \\
\hline BMI, $\mathrm{kg} / \mathrm{m}^{2}$ & Median (min-max) & $26.7(15-40)$ & $27.3(19-37)$ & 0.403 \\
\hline \multirow[t]{3}{*}{ Performance status, n (\%) } & 0 & $36(14.9 \%)$ & $14(16.3 \%)$ & 0.892 \\
\hline & 1 & $189(78.1 \%)$ & $69(80.2 \%)$ & 0.794 \\
\hline & 2 & $17(7.0 \%)$ & $3(3.5 \%)$ & 0.360 \\
\hline \multirow[t]{7}{*}{ Clinical stage at diagnosis*, n (\%) } & IA & $4(1.7 \%)$ & $2(2.6 \%)$ & $>0.99$ \\
\hline & IB & $7(3.1 \%)$ & $0(0 \%)$ & 0.266 \\
\hline & IIA & $0(0 \%)$ & $0(0 \%)$ & 0.266 \\
\hline & IIB & $7(3.1 \%)$ & $7(9.1 \%)$ & 0.061 \\
\hline & IIIA & $41(17.9 \%)$ & $21(27.3 \%)$ & 0.108 \\
\hline & IIIB & $54(23.6 \%)$ & $14(18.2 \%)$ & 0.408 \\
\hline & IV & $116(50.7 \%)$ & $33(42.9 \%)$ & 0.293 \\
\hline \multirow[t]{3}{*}{ Comorbidities, n (\%) } & Hypertension & $90(37.0 \%)$ & $20(23.3 \%)$ & 0.028 \\
\hline & Thromboembolism & $15(6.2 \%)$ & $3(3.5 \%)$ & 0.506 \\
\hline & Tumor duplicity & $21(8.6 \%)$ & $3(3.5 \%)$ & 0.181 \\
\hline \multirow[t]{3}{*}{ Number of treatment lines, $\mathrm{n}(\%)$} & 1 & $237(97.5 \%)$ & $80(93.0 \%)$ & 0.114 \\
\hline & 2 & $6(2.5 \%)$ & $5(5.8 \%)$ & 0.257 \\
\hline & $\geq 3$ & $0(0 \%)$ & $1(1.2 \%)$ & 0.587 \\
\hline Chemotherapy pre-treatment, $\mathrm{n}(\%)$ & Yes & $175(72.0 \%)$ & $34(39.5 \%)$ & $<0.001$ \\
\hline \multirow[t]{3}{*}{ Personalized treatment, $\mathrm{n}(\%)$} & Erlotinib & $238(96.7 \%)$ & $58(63.0 \%)$ & $<0.001$ \\
\hline & Nivolumab & $0(0 \%)$ & $32(34.8 \%)$ & $<0.001$ \\
\hline & Pemetrexed & $8(3.3 \%)$ & $2(2.2 \%)$ & 0.873 \\
\hline Radiotherapy, n (\%) & Yes & $100(41.2 \%)$ & $45(52.3 \%)$ & 0.095 \\
\hline Lung surgery, $\mathrm{n}(\%)$ & Yes & $31(12.8 \%)$ & $16(18.6 \%)$ & 0.249 \\
\hline Presence of side-effects, $\mathrm{n}(\%)$ & Yes & $114(46.9 \%)$ & $25(29.1 \%)$ & 0.006 \\
\hline \multirow[t]{5}{*}{ Grade of side-effects, n (\%) } & Total & 172 & 38 & \\
\hline & 1 & $73(42.2 \%)$ & $5(13.2 \%)$ & 0.001 \\
\hline & 2 & $65(37.8 \%)$ & $16(42.1 \%)$ & 0.756 \\
\hline & 3 & $28(16.3 \%)$ & $15(39.5 \%)$ & 0.003 \\
\hline & 4 & $6(3.5 \%)$ & $2(5.3 \%)$ & 0.961 \\
\hline \multirow{3}{*}{ Type of side-effects, n (\%) } & Dermatitis & $103(56.3 \%)$ & $17(44.7 \%)$ & 0.262 \\
\hline & Liver enzyme elevation & $6(3.3 \%)$ & $0(0 \%)$ & 0.560 \\
\hline & Other & $72(39.3 \%)$ & $21(55.3 \%)$ & 0.103 \\
\hline \multirow[t]{3}{*}{ Radiotherapy and, n (\%) } & Total & 100 & 45 & \\
\hline & 1 treatment line & $99(99.0 \%)$ & $43(95.6 \%)$ & 0.473 \\
\hline & $\geq 2$ treatment lines & $1(1.0 \%)$ & $2(4.4 \%)$ & 0.473 \\
\hline
\end{tabular}

OS: Overall survival; PFS: progression-free survival; CI: confidence interval; BMI: body mass index; EGFR: endothelial-growth factor receptor gene mutation; $A L K$ : anaplastic lymphoma kinase gene mutation. *Seventh edition of TNM classification of malignant tumors (8).

A comparison of cohorts 1 and 2 showed more prevalent comorbidities in cohort 1 (both for adenocarcinoma and SCC). In cohort 2 , comorbidities were less abundant, most probably reflecting a more appropriate patient selection for the modernera treatment administration. Comparison between groups of 2 year-survivors from both adenocarcinoma and SCC showed no differences in demography, comorbidities or treatment characteristics. These data suggest that the prominent increase in probability of 2-year survival observed in cohort 2 was driven mainly by introduction of new (personalized) treatments. Of the patients with adenocarcinoma, cohort 2 patients were treated more frequently by second-generation TKIs, bevacizumab, crizotinib and immunotherapy. The introduction of these treatments resulted in a reduced rate of erlotinib use (i.e. the first TKI approved in the Czech Republic) in cohort 2. The advanced therapeutic properties of the newest medications resulted in distinctive improvement of outcomes in cohort 2. On the other hand, in SCC subgroups, cohort 1 patients had fewer opportunities in terms of newer medications (compared to those with adenocarcinoma). 
Table IV. Cox proportional hazards model for patients surviving $\geq 2$ years.

\begin{tabular}{|c|c|c|c|}
\hline Parameter & Parameter & $\operatorname{HR}(95 \% \mathrm{CI})$ & $p$-Value \\
\hline \multirow[t]{2}{*}{ Adenocarcinoma } & Cohort 1 & ref. & \\
\hline & Cohort 2 & $0.666(0.541-0.821)$ & 0.001 \\
\hline \multirow[t]{3}{*}{ Performance status } & 0 & ref. & \\
\hline & 1 & $1.267(1.033-1.554)$ & 0.023 \\
\hline & 2 & $2.356(1.518-3.658)$ & 0.001 \\
\hline \multirow[t]{5}{*}{ Clinical stage at diagnosis* } & IA & ref. & \\
\hline & IIA & $2.289(1.050-4.991)$ & 0.037 \\
\hline & IIB & $2.671(1.137-6.276)$ & 0.024 \\
\hline & IIIB & $2.023(1.101-3.717)$ & 0.023 \\
\hline & IV & $2.600(1.475-4.584)$ & 0.001 \\
\hline \multirow[t]{3}{*}{ Number of treatment lines } & 1 & ref. & \\
\hline & 2 & $0.597(0.458-0.778)$ & 0.001 \\
\hline & $\geq 3$ & $0.299(0.161-0.556)$ & 0.001 \\
\hline \multirow[t]{2}{*}{ Personalized treatment } & Bevacizumab & $1.894(1.264-2.837)$ & 0.002 \\
\hline & Pemetrexed & $1.911(1.376-2.665)$ & 0.001 \\
\hline \multirow[t]{4}{*}{ SCC } & Cohort 1 & ref. & \\
\hline & Cohort 2 & $0.740(0.484-1.132)$ & 0.166 \\
\hline & Chemotherapy pre-treatment & $1.416(1.040-1.928)$ & 0.027 \\
\hline & Side-effects & $0.714(0.541-0.942)$ & 0.017 \\
\hline
\end{tabular}

SCC: Squamous cell carcinoma; HR: hazard ratio; CI: confidence intervaI; ref: referent. *Seventh edition of TNM classification of malignant tumors (8).

However, the treatment effectiveness of immunotherapy seemed to facilitate major improvement in probability of 2year survival in patients with SCC of cohort 2. Another key point explaining the distinctive improvement of outcomes during the study period is the increasing possibility of sequential personalized treatment. This was evident in our adenocarcinoma cohorts where use of three lines or more of treatment was more frequent in cohort $2(12.1 \% v s .4 \%$ in cohort $1 ; p<0.001)$.

Since 2011-12 (until 2015-16), the availability of modern treatments in our cohort (i.e. in the Czech Republic) increased from antifolates (pemetrexed), first-generation TKIs (erlotinib, gefitinib), antiangiogenic drugs (bevacizumab) to also second-generation TKIs (afatinib), third-generation TKIs (osimertinib), ALK inhibitors (crizotinib) and immunotherapy (nivolumab). The introduction of these medications resulted in a significantly longer OS compared to standard chemotherapy. Pemetrexed was introduced in combination with cisplatin after its efficacy was confirmed for patients with adenocarcinoma in the trial by Scagliotti et al. (OS=12.6 months vs. 10.9 months for cisplatin/gemcitabine) (9). Bevacizumab, an antibody against vascular endothelial growth factor (VEGFR), was found to be most effective in a triplet regimen with chemotherapy (OS=12.3 vs. 10.3 months, $\mathrm{PFS}=6.2$ vs. 4.5 months compared with standard chemotherapy) in patients with non-squamous histology NSCLC (10). In addition, pemetrexed and bevacizumab demonstrated further improvement in PFS in so-called continuation maintenance therapy (11). The first biological agent approved in 2003 by the United States Food and Drug Admisistration (FDA) for NSCLC treatment was the TKI gefitinib $(12,13)$. Gefitinib showed high efficacy especially in the Asians, female and never-smoker subpopulations of patients with adenocarcinoma (i.e. increase in PFS of 9-10 months) and also led to the discovery of mutations of EGFR $(12,13)$. The more recently introduced TKIs were erlotinib, afatinib and osimertinib (4). Erlotinib-treated patients of European origin with EGFR-positive adenocarcinoma showed increased PFS (9.7 vs. 5.2 months) compared to the chemotherapy-treated group in the EURTAC trial (14). In a face-to-face comparison of three TKIs (erlotinib, gefitinib and afatinib), afatinib showed the highest efficacy in terms of PFS duration (14 vs. 13.7 vs. 19.1 months, respectively) (15). Erlotinib is also used as a second-line or further treatment in patients with SCC due to more favorable toxicity profile compared to conventional chemotherapy (16). For those with adenocarcinoma with the EGFR T790M mutation, osimertinib is available, offering the possibility of prolonged survival compared to adenocarcinoma treated with erlotinib or gefitinib (PFS =18.9 vs. 10.2 months (17). The first drug of the TKI group that was approved in the Czech Republic was erlotinib.

Another important mutation related to different prognosis of patients with adenocarcinoma is the echinoderm microtubule-associated protein-like 4 (EML4)-ALK translocation (4). The first available drug of the ALK inhibitor group was crizotinib (PFS=10 months in $A L K$ - 
Table V. Comparison of adenocarcinoma patients surviving $\geq 2$ years.

\begin{tabular}{|c|c|c|c|c|}
\hline Parameter & Parameter & Cohort $1(\mathrm{~N}=102)$ & Cohort $2(\mathrm{~N}=46)$ & $p$-Value \\
\hline \multirow[t]{2}{*}{ Survival, months } & Median OS (95\% CI) & $36.9(32.3-47.2)$ & NR & \\
\hline & Median PFS (95\% CI) & $15.8(11.9-22.5)$ & $17.6(11.4-23.9)$ & 0.594 \\
\hline Age, years & Median (min-max) & $64,1(32-83)$ & $64,8(25-90)$ & 0.659 \\
\hline Gender & $\operatorname{Men}(\mathrm{n}, \%)$ & $48(47,1 \%)$ & $17(37,0 \%)$ & 0.333 \\
\hline Smoking history, n (\%) & Past or current smoker & $63(61.8 \%)$ & $27(58.7 \%)$ & 0.863 \\
\hline \multirow[t]{3}{*}{ Performance status, n (\%) } & 0 & $36(35.3 \%)$ & $16(33.3 \%)$ & 0.966 \\
\hline & 1 & $64(62.7 \%)$ & $30(66.7 \%)$ & 0.787 \\
\hline & 2 & $2(2.0 \%)$ & $0(0 \%)$ & 0.862 \\
\hline \multirow[t]{7}{*}{ Clinical stage at diagnosis*, $\mathrm{n}(\%)$} & IA & $7(7.0 \%)$ & $1(2.2 \%)$ & 0.424 \\
\hline & IB & $2(2.0 \%)$ & $2(4.3 \%)$ & 0.794 \\
\hline & IIA & $2(2.0 \%)$ & $1(2.2 \%)$ & 0.842 \\
\hline & IIB & $0(0 \%)$ & $2(4.3 \%)$ & 0.182 \\
\hline & IIIA & $9(9.0 \%)$ & $5(10.9 \%)$ & 0.957 \\
\hline & IIIB & $17(17.0 \%)$ & $4(8.7 \%)$ & 0.283 \\
\hline & IV & $65(65.0 \%)$ & $32(69.6 \%)$ & 0.558 \\
\hline \multirow[t]{3}{*}{ Mutation status, n (\%) } & Total & 77 & 42 & \\
\hline & $E G F R$-positive & $29(37.7 \%)$ & $15(35.7 \%)$ & 0.991 \\
\hline & $A L K$-positive & $4(5.2 \%)$ & $2(4.8 \%)$ & $>0.99$ \\
\hline \multirow[t]{3}{*}{ Comorbidities, n (\%) } & Hypertension & $44(43.1 \%)$ & $17(37.0 \%)$ & 0.598 \\
\hline & Thromboembolism & $7(6.9 \%)$ & $4(8.7 \%)$ & 0.956 \\
\hline & Tumor duplicity & $10(9.8 \%)$ & $3(6.5 \%)$ & 0.734 \\
\hline \multirow[t]{3}{*}{ Number of treatment lines, $\mathrm{n}(\%)$} & 1 & $73(71.6 \%)$ & $36(78.3 \%)$ & 0.513 \\
\hline & 2 & $27(26.5 \%)$ & $10(21.7 \%)$ & 0.682 \\
\hline & $\geq 3$ & $2(2.0 \%)$ & $0(0 \%)$ & 0.852 \\
\hline Chemotherapy pre-treatment, $\mathrm{n}(\%)$ & Yes & $27(26.5 \%)$ & $5(10.9 \%)$ & 0.055 \\
\hline \multirow[t]{7}{*}{ Modern-era treatment, n (\%) } & Afatinib & $0(0 \%)$ & $7(12.5 \%)$ & $<0.001$ \\
\hline & Bevacizumab & $11(8.3 \%)$ & $12(21.4 \%)$ & 0.022 \\
\hline & Crizotinib & $2(1.5 \%)$ & $0(0 \%)$ & 0.885 \\
\hline & Erlotinib & $39(29.3 \%)$ & $3(5.4 \%)$ & 0.001 \\
\hline & Gefitinib & $17(12.8 \%)$ & $7(12.5 \%)$ & $>0.99$ \\
\hline & Nivolumab & $1(0.8 \%)$ & $2(3.6 \%)$ & 0.436 \\
\hline & Pemetrexed & $63(47.4 \%)$ & $24(42.8 \%)$ & 0.683 \\
\hline Radiotherapy, n (\%) & Yes & $19(18.6 \%)$ & $6(13.0 \%)$ & 0.547 \\
\hline
\end{tabular}

OS: Overall survival; PFS: progression-free survival; CI: confidence interval; NR: not reached; $E G F R$ : endothelial-growth factor receptor gene mutation; ALK: anaplastic lymphoma kinase gene mutation. *Seventh edition of TNM classification of malignant tumors (8).

mutated patients), followed by ceritinib and brigatinib (these two drugs are currently unavailable in the Czech Republic) (18-20). The most promising drug of the ALK inhibitor group is alectinib (4). The outstanding efficacy of alectinib was demonstrated recently in the ALEX study where the superiority of alectinib versus crizotinib in previously untreated ALK-positive patients was extremely prominent (PFS: $34.8 v s$. crizotinib 10.9 months) (5). Last but not least, in the past 5 years, a completely new class of anticancer treatment has been introduced - immunotherapy. These drugs target programmed cell-death receptor (PD1) or programmed cell-death ligand 1 (PD-L1). Of these drugs, nivolumab, pembrolizumab, durvalumab and atezolizumab were approved by both the FDA and European Medicines Agency; however, as of August 2019, atezolizumab and durvalumab were still not yet available for use in the Czech Republic. In a comparative analysis of three immunotherapeutic drugs, both nivolumab, atezolizumab and pembrolizumab led to better OS $(\mathrm{HR}=0.72$ vs. 0.82$)$ and $\mathrm{PFS}(\mathrm{HR}=0.84$ vs. 0.97$)$ compared to chemotherapy in patients with advanced-stage NSCLC (21). Of the PD1/PD-L1 inhibitors, the most impressive treatment results were observed for atezolizumab ( $\mathrm{OS}=13.8$ vs. 9.6 months for chemotherapy) (22). On the other hand, pembrolizumab showed efficacy in patients with adenocarcinoma with $>50 \%$ PD-L1 expression $(\mathrm{PFS}=10.3 \mathrm{vs}$. 6 months compared to chemotherapy) (23).

Our observation of notable increase in the 2-year survival rate among patients with advanced-stage with NSCLC during the past few years has important consequences, including quality of life (QoL) aspects, psychological factors and also increased healthcare expenditures. In terms of psychological aspects, patients with lung cancer were reported to experience the highest rate of distress compared to patients with other types of 
Table VI. Comparison of patients with squamous cell carcinoma surviving $\geq 2$ years.

\begin{tabular}{|c|c|c|c|c|}
\hline Parameter & Parameter & Cohort $1(\mathrm{~N}=16)$ & Cohort $2(\mathrm{~N}=10)$ & $p$-Value \\
\hline \multirow[t]{2}{*}{ Survival, months } & Median OS $(95 \% \mathrm{CI})$ & $34.5(27.8-\mathrm{NR})$ & NR & \\
\hline & Median PFS (95\% CI) & $16.6(10.6--)$ & $14.4(3.0--)$ & 0.638 \\
\hline Age, years & Median (min-max) & $66.4(54-81)$ & $66.6(60-87)$ & 0.236 \\
\hline Gender & $\operatorname{Men}(\mathrm{N}, \%)$ & $12(75.0 \%)$ & $8(80.0 \%)$ & $>0.99$ \\
\hline Smoking history, n (\%) & Past or current smoker & $14(87.5 \%)$ & $10(100 \%)$ & 0.684 \\
\hline \multirow[t]{3}{*}{ Performance status, n (\%) } & 0 & $4(25.0 \%)$ & $0(0 \%)$ & 0.246 \\
\hline & 1 & $11(68.8 \%)$ & $9(900 \%)$ & 0.440 \\
\hline & 2 & $1(6.2 \%)$ & $1(10.0 \%)$ & $>0.99$ \\
\hline \multirow[t]{7}{*}{ Clinical stage at diagnosis*, $\mathrm{n}(\%)$} & IA & $0(0 \%)$ & $0(0 \%)$ & $>0.99$ \\
\hline & IB & $1(6.2 \%)$ & $0(0 \%)$ & $>0.99$ \\
\hline & IIA & $0(0 \%)$ & $0(0 \%)$ & $>0.99$ \\
\hline & IIB & $0(0 \%)$ & $1(11.1 \%)$ & 0.766 \\
\hline & IIIA & $5(31.2 \%)$ & $3(33.3 \%)$ & $>0.99$ \\
\hline & IIIB & $3(18.8 \%)$ & $1(11.1 \%)$ & $>0.99$ \\
\hline & IV & $7(43.8 \%)$ & $4(44.4 \%)$ & $>0.99$ \\
\hline \multirow[t]{3}{*}{ Comorbidities, n (\%) } & Hypertension & $7(43.8 \%)$ & $3(30.0 \%)$ & 0.774 \\
\hline & Thromboembolism & $2(12.5 \%)$ & $0(0 \%)$ & 0.684 \\
\hline & Tumor duplicity & $1(6.2 \%)$ & $0(0 \%)$ & $>0.99$ \\
\hline \multirow[t]{3}{*}{ Number of treatment lines, $\mathrm{n}(\%)$} & 1 & $15(93.8 \%)$ & $9(90.0 \%)$ & $>0.99$ \\
\hline & 2 & $1(6.2 \%)$ & $1(10.0 \%)$ & $>0.99$ \\
\hline & $\geq 3$ & $0(0 \%)$ & $0(0 \%)$ & $>0.99$ \\
\hline Chemotherapy pre-treatment, $\mathrm{n}(\%)$ & Yes & $9(56.3 \%)$ & $4(40.0 \%)$ & 0.687 \\
\hline \multirow[t]{3}{*}{ Personalized treatment, n (\%) } & Erlotinib & $15(88.2 \%)$ & $3(27.3 \%)$ & 0.004 \\
\hline & Nivolumab & $0(0 \%)$ & $8(72.3 \%)$ & $<0.001$ \\
\hline & Pemetrexed & $2(11.8 \%)$ & $0(0 \%)$ & 0.668 \\
\hline Radiotherapy, n (\%) & Yes & $8(50.0 \%)$ & $6(60.0 \%)$ & 0.926 \\
\hline
\end{tabular}

OS: Overall survival; PFS: progression-free survival; CI: confidence interval; NR: not reached; EGFR: endothelial-growth factor receptor gene mutation; $A L K$ : anaplastic lymphoma kinase gene mutation. *Seventh edition of TNM classification of malignant tumors (8).

cancer (24). Despite this fact, such patients appear to receive psychological or supportive care less frequently than patients with other types of cancer (25). The most probable reason for this is the practice of giving specialized psychological care to patients with cancer with a supposed longer life expectancy (e.g. breast cancer or chronic lymphatic leukemia) (26). The results of our study show that a large proportion (almost one half) of currently treated patients with advanced-stage with NSCLC are expected to survive longer than 2 years. This observation emphasizes the need for improvement in the field of psychological support provided to these patients. A psychological intervention may positively influence not only the patient's perception of symptoms, but also QoL outcomes (27). The QoL aspects not only influence the disease and treatment tolerance, but also have direct linkage to OS since patients with higher QoL scores receive more aggressive treatment (28). Economic aspects have also emerged and continue to play an important role in treatment decision-making of caregivers and administrators, as a number of new drugs are being approved in different regions of the world (29). Obviously, longer survival of patients with NSCLC definitely increases the overall healthcare costs for this category of patients. In terms of cost-effectiveness, a faceto-face comparison of three TKI treatment regimens (gefitinib, erlotinib and afatinib), gefitinib was found to be the most cost-effective TKI molecule (30). In a study by Tink et al., TKIs (erlotinib and afatinib) were found to be more cost-effective compared to cisplatin-pemetrexed treatment (31). However, the overall expenses for a patient with NSCLC should not be confused with the costeffectiveness of a treatment.

The main strength of our study is that the data are representative of real-life settings. The data were prospective, being collected since 2011 at 11 centers in the Czech Republic and reflect the evolution of anticancer agents and their use in a Central Europe-based real-life cohort. Importantly, our results facilitate a view on an unselected population of individuals with advanced stages of NSCLC, receiving modern-era treatments of various classes. Probably the most valuable feature regarding our cohort is that it also includes data of patients with sequenced treatment (i.e. two and more lines of anticancer treatment). In contrast, most of the clinical trials operate with data of selected populations 
treated with a single anticancer drug and fulfilling multiple exclusion criteria. Our approach allows us to look at patients with NSCLC from a more global point of view. This view, consequently, shows that the prognosis of patients with NSCLC (in our results expressed as 2-year survival) treated with modern treatments notably improved between the years 2011-12 and 2015-16. The rapid pharmaceutical progress and the ongoing introduction of new therapeutic agents since 2016 is expected to further improve prognosis of patients with NSCLC. In particular, the newer immunotherapy agents and alectinib (of the ALK inhibitor group) seem to be very promising in terms of future progress, especially if treatment sequencing is possible $(5,21)$. Another important issue is to identify those patients, using biological, biochemical or genetic markers, who would be most amenable to the use of specific molecules, as well as of their combinations or sequences.

\section{Limitations}

There are several limitations in this study. Firstly, the TULUNG Registry does not include patients with NSCLC treated only with standard chemotherapy. Secondly, systematic assessment of QoL measures and psychological aspects is not part of the TULUNG Registry. This fact left us unable to compare these measures in the predefined cohorts and assess their evolution over time. Thirdly, the data collection within the TULUNG Registry is not focused on evaluation of systematic comorbidities during inclusion and the disease course (e.g. the Charlson comorbidity index). Only preselected comorbidities are assessed on a systematic base (e.g. hypertension, thromboembolism, tumor/cancer multiplicity). As a result, potential other differences between cohorts 1 and 2 might have been overlooked. However, the presence of severe comorbidities (i.e. performance status grades >2) would completely contraindicate the use of modern drugs.

\section{Conclusion}

In this study, we learned that the probability of 2-year survival among patients with advanced-stage (stages IIIBIV) NSCLC in the Czech Republic has dramatically increased during the period between 2011-12 and 2015-16. In a large proportion of patients with advanced-stage disease, NSCLC may now be considered a chronic disease. We speculate that many of these patients nowadays experience different psychological and QoL problems, which stresses the need for more intensive psychological and QoL support from caregivers. With the ongoing progress in treatment opportunities, we may expect further improvement in long-term prognosis of patients with advanced-stage NSCLC.

\section{Conflicts of Interest}

The Authors declare no conflicts of interest relevant to this study.

\section{Authors' Contributions}

All Authors contributed to the data collection, analysis and interpretation or writing of the manuscript. M.B., K.B., B.K. and M.B. had full access to all TULUNG data regarding this study and take the responsibility for the data integrity and accuracy. M.B. and K.B. presented the idea of 2-year survival analysis from different time periods and designed the current study. M.B., L.K., J.K., M.H., L.H. and I.G. collected the data. B.K. and M.B. carried out the statistical analysis. V.K., J.S. and M.P. designed the TULUNG Registry in 2010. M.B., K.B., B.K., M.B., J.S. and V.K. drafted the manuscript. J.S. and V.K. secured funding. All Authors critically revised the manuscript in terms of intellectual content and approved the submitted version.

\section{Acknowledgements}

The Authors would like to thank the physicians participating in the TULUNG Registry, namely: Marcela Tomiskova, Andrea Benejova and Helena Coupkova (all from Brno), Renata Jiraskova, Zuzana Tothova, Petr Zatloukal, Dimka Sixtova, Marketa Cernovska, Iva Hulova, Daniela Duskova and Hana Janoskova (all from Prague).

\section{Funding}

TULUNG Registry and this study were funded by Ministry of Health of the Czech Republic (MH CZ-DRO FNBr 65269705) and by a consortium of pharmaceutical companies (Bristol Myers Squibb, Pfizer, Astra Zeneca, Roche, MSD and Boehringer Ingelheim). All companies supported the TULUNG Registry via unrestricted research grants. The sponsors had no role in the design of this study, in data collection and analysis or in preparation of the article. The opinions, results, and conclusions reported in this article are completely independent of the funding sources.

\section{References}

1 Spiro SG and Silvestri GA: One hundred years of lung cancer. Am J Respir Crit Care Med 172(5): 523-529, 2005. PMID: 15961694.

2 Cancer Facts Sheets: Lung Cancer. Globocan Cancer Observatory, World Health Organisation, 2018. Available at: https://gco.iarc.fr/ today/data/factsheets/cancers/15-Lung-fact-sheet.pdf Last accessed: July $23^{\text {rd }}, 2019$.

3 Novotvary 2016, komplet (Cancer Incidence in the Czech Republic, 2016): Institute of Health Information and Statistics of the Czech Republic, 2016. Available at: http://www.uzis.cz/ en/node/8139 Last accessed: August $18^{\text {th }}, 2019$.

4 Pakkala S and Ramalingam SS: Personalized therapy for lung cancer: Striking a moving target. JCI Insight 3(15): 120858, 2018. PMID: 30089719. DOI: 10.1172/jci.insight.120858

5 Camidge DR, Dziadziuszko R, Peters S, Mok T, Noe J, Nowicka M, Gadgeel SM, Cheema P, Pavlakis N, de Marinis F, Cho BC, Zhang L, Moro-Sibilot D, Liu T, Bordogna W, Balas B, Müller B and Shaw AT: Updated efficacy and safety data and impact of the EML4-ALK fusion variant on the efficacy of alectinib in 
untreated ALK-positive advanced non-small cell lung cancer in the global phase III ALEX study. J Thorac Oncol 14(7): 12331243, 2019. PMID: 30902613. DOI: 10.1016/j.jtho.2019.03.007

6 Noncommunicable diseases: World Health Organisation, 2018. Available at: https://www.who.int/news-room/fact-sheets/detail/ noncommunicable-diseases Last accessed: July $2^{3 \text { rd }}, 2019$.

7 Bernell S and Howard SW: Use your words carefully: What is a chronic disease? Front Public Health 4: 159, 2016. PMID: 27532034. DOI: 10.3389/fpubh.2016.00159

8 Goldstraw P and Groome P: Lung and pleural tumours. In: Sobin LH, Gospodarowicz MK, Wittekind C (eds.): UICC TNM Classification of Malignant Tumours Seventh Edition. Hoboken, New Jersey, Wiley-Blackwell, pp. 136-146, 2009.

9 Scagliotti GV, Parikh P, von Pawel J, Biesma B, Vansteenkiste J, Manegold C, Serwatowski P, Gatzemeier U, Digumarti R, Zukin M, Lee JS, Mellemgaard A, Park K, Patil S, Rolski J, Goksel T, de Marinis F, Simms L, Sugarman KP and Gandara D: Phase III study comparing cisplatin plus gemcitabine with cisplatin plus pemetrexed in chemotherapy-naive patients with advanced-stage non-small-cell lung cancer. J Clin Oncol 26(21): 3543-3551, 2008. PMID: 18506025. DOI: $10.1200 / \mathrm{JCO}$. 2007.15.0375

10 Sandler A, Gray R, Perry MC, Brahmer J, Schiller JH, Dowlati A, Lilenbaum R and Johnson DH: Paclitaxel-carboplatin alone or with bevacizumab for non-small-cell lung cancer. N Engl J Med 355(24): 2542-2550, 2006. PMID: 17167137. DOI: 10.1056/ NEJMoa061884

11 Reck M, Paz-Ares LG, de Marinis F, Molinier O, Sahoo TP, Laack E, John W, Zimmermann AH, Visseren-Grul C and Gridelli C: PARAMOUNT: Descriptive subgroup analyses of final overall survival for the phase III study of maintenance pemetrexed versus placebo following induction treatment with pemetrexed plus cisplatin for advanced nonsquamous non-smallcell lung cancer. J Thorac Oncol 2: 205-213, 2014. PMID: 24419418. DOI: $10.1097 /$ JTO.0000000000000076

12 Fukuoka M, Yano S, Giaccone G, Tamura T, Nakagawa K, Douillard JY, Nishiwaki Y, Vansteenkiste J, Kudoh S, Rischin D, Eek R, Horai T, Noda K, Takata I, Smit E, Averbuch S, Macleod A, Feyereislova A, Dong RP and Baselga J: Multi-institutional randomized phase II trial of gefitinib for previously treated patients with advanced non-small-cell lung cancer (The IDEAL 1 Trial) [corrected]. J Clin Oncol 21(12): 2237-2246, 2003. PMID: 12748244. DOI: 10.1200/JCO.2003.10.038

13 Miller VA, Kris MG, Shah N, Patel J, Azzoli C, Gomez J, Krug LM, Pao W, Rizvi N, Pizzo B, Tyson L, Venkatraman E, BenPorat L, Memoli N, Zakowski M, Rusch V and Heelan RT: Bronchioloalveolar pathologic subtype and smoking history predict sensitivity to gefitinib in advanced non-small-cell lung cancer. J Clin Oncol 22(6): 1103-1109, 2004. PMID: 15020612.

14 Rosell R, Carcereny E, Gervais R, Vergnenegre A, Massuti B, Felip E, Palmero R, Garcia-Gomez R, Pallares C, Sanchez JM, Porta R, Cobo M, Garrido P, Longo F, Moran T, Insa A, De Marinis F, Corre R, Bover I, Illiano A, Dansin E, de Castro J, Milella M, Reguart N, Altavilla G, Jimenez U, Provencio M, Moreno MA, Terrasa J, Muñoz-Langa J, Valdivia J, Isla D, Domine M, Molinier O, Mazieres J, Baize N, Garcia-Campelo R, Robinet G, Rodriguez-Abreu D, Lopez-Vivanco G, Gebbia V, Ferrera-Delgado L, Bombaron P, Bernabe R, Bearz A, Artal A, Cortesi E, Rolfo C, Sanchez-Ronco M, Drozdowskyj A, Queralt C, de Aguirre I, Ramirez JL, Sanchez JJ, Molina MA, Taron M,
Paz-Ares L and Spanish Lung Cancer Group in collaboration with Groupe Français de Pneumo-Cancérologie and Associazione Italiana Oncologia Toracica: Erlotinib versus standard chemotherapy as first-line treatment for European patients with advanced EGFR mutation-positive non-small-cell lung cancer (EURTAC): a multicentre, open-label, randomised phase 3 trial. Lancet Oncol 13(3): 239-246, 2012. PMID: 22285168. DOI: 10.1016/S1470-2045(11)70393-X

15 Kim Y, Lee SH, Ahn JS, Ahn MJ, Park K and Sun JM: Efficacy and safety of afatinib for EGFR-mutant non-small cell lung cancer, compared with gefitinib or erlotinib. Cancer Res Treat 51(2): 502509, 2019. PMID: 29898592. DOI: 10.4143/crt.2018.117

16 Ciuleanu T, Stelmakh L, Cicenas S, Miliauskas S, Grigorescu AC, Hillenbach C, Johannsdottir HK, Klughammer B and Gonzalez EE: Efficacy and safety of erlotinib versus chemotherapy in second-line treatment of patients with advanced, non-small-cell lung cancer with poor prognosis (TITAN): A randomised multicentre, open-label, phase 3 study. Lancet Oncol 13(3): 300308, 2012. PMID: 22277837. DOI: 10.1016/S1470-2045(11) 70385-0

17 Soria JC, Ohe Y, Vansteenkiste J, Reungwetwattana T, Chewaskulyong B, Lee $\mathrm{KH}$, Dechaphunkul A, Imamura F, Nogami N, Kurata T, Okamoto I, Zhou C, Cho BC, Cheng Y, Cho EK, Voon PJ, Planchard D, Su WC, Gray JE, Lee SM, Hodge R, Marotti M, Rukazenkov Y, Ramalingam SS and FLAURA Investigators: Osimertinib in untreated EGFR-mutated advanced non-small-cell lung cancer. N Engl J Med 378(2): 113125, 2018. PMID: 29151359. DOI: 10.1056/NEJMoa1713137

18 Camidge DR, Bang YJ, Kwak EL, Iafrate AJ, Varella-Garcia M, Fox SB, Riely GJ, Solomon B, Ou SH, Kim DW, Salgia R, Fidias P, Engelman JA, Gandhi L, Jänne PA, Costa DB, Shapiro GI, Lorusso P, Ruffner K, Stephenson P, Tang Y, Wilner K, Clark JW and Shaw AT: Activity and safety of crizotinib in patients with ALK-positive non-small-cell lung cancer: Updated results from a phase 1 study. Lancet Oncol 13(10): 1011-1019, 2012. PMID: 22954507. DOI: 10.1016/S1470-2045(12)70344-3

19 Kim DW, Mehra R, Tan DSW, Felip E, Chow LQM, Camidge DR, Vansteenkiste J, Sharma S, De Pas T, Riely GJ, Solomon BJ, Wolf J, Thomas M, Schuler M, Liu G, Santoro A, Sutradhar S, Li S, Szczudlo T, Yovine A and Shaw AT: Activity and safety of ceritinib in patients with ALK-rearranged non-small-cell lung cancer (ASCEND-1): Updated results from the multicentre, open-label, phase 1 trial. Lancet Oncol. 17(4): 452-463, 2016. PMID: 26973324. DOI: 10.1016/S1470-2045(15)00614-2

20 Gettinger SN, Bazhenova LA, Langer CJ, Salgia R, Gold KA, Rosell R, Shaw AT, Weiss GJ, Tugnait M, Narasimhan NI, Dorer DJ, Kerstein D, Rivera VM, Clackson T, Haluska FG and Camidge DR: Activity and safety of brigatinib in $A L K$ rearranged non-small-cell lung cancer and other malignancies: a single-arm, open-label, phase 1/2 trial. Lancet Oncol 17(12): 1683-1696, 2016. PMID: 27836716. DOI: 10.1016/S14702045(16)30392-8

21 Khan M, Lin J, Liao G, Tian Y, Liang Y, Li R, Liu M and Yuan $\mathrm{Y}$ : Comparative analysis of immune checkpoint inhibitors and chemotherapy in the treatment of advanced non-small cell lung cancer: A meta-analysis of randomized controlled trials. Medicine 97(33), 2018. PMID: 30113497. DOI: 10.1097/ MD.0000000000011936

22 Giroux Leprieur E, Dumenil C, Julie C, Giraud V, Dumoulin J, Labrune $\mathrm{S}$ and Chinet T: Immunotherapy revolutionises non- 
small-cell lung cancer therapy: Results, perspectives and new challenges. Eur J Cancer 78: 16-23, 2017. PMID: 28407528. DOI: $10.1016 /$ j.ejca.2016.12.041

23 Reck M, Rodríguez-Abreu D, Robinson AG, Hui R, Csőszi T, Fülöp A, Gottfried M, Peled N, Tafreshi A, Cuffe S, O'Brien M, Rao S, Hotta K, Leiby MA, Lubiniecki GM, Shentu Y, Rangwala R, Brahmer JR and KEYNOTE-024 Investigators: Pembrolizumab versus Chemotherapy for PD-L1-positive nonsmall-cell lung cancer. N Engl J Med 375(19): 1823-1833, 2016. PMID: 27718847.

24 Zabora J, BrintzenhofeSzoc K, Curbow B, Hooker C and Piantadosi S: The prevalence of psychological distress by cancer site. Psychooncology 10(1): 19-28, 2001. PMID: 11180574.

25 Sanders SL, Bantum EO, Owen JE, Thornton AA and Stanton AL: Supportive care needs in patients with lung cancer. Psychooncology 19(5): 480-489, 2010. PMID: 19434625. DOI: 10.1002/pon.1577

26 Carlsen K, Jensen AB, Jacobsen E, Krasnik M and Johansen C: Psychosocial aspects of lung cancer. Lung Cancer 47(3): 293 300, 2005. PMID: 15713512.

27 Pearman T: Psychosocial factors in lung cancer. J Psychosoc Oncol 26(1): 69-80, 2008. PMID: 18077263.

28 Earle CC: Outcomes research in lung cancer. J Natl Cancer Inst Monogr 33: 56-77, 2004. PMID: 15504920.
29 Gu X, Zhang Q, Chu YB, Zhao YY, Zhang YJ, Kuo D, Su B and $\mathrm{Wu}$ B: Cost-effectiveness of afatinib, gefitinib, erlotinib and pemetrexed-based chemotherapy as first-line treatments for advanced non-small cell lung cancer in China. Lung Cancer 127: 84-89, 2019. PMID: 30642557. DOI: 10.1016/j.lungcan. 2018.11.029

30 Kimura M, Yasue F, Usami E, Kawachi S, Iwai M, Go M, Ikeda $\mathrm{Y}$ and Yoshimura T: Cost-effectiveness and safety of the molecular targeted drugs afatinib, gefitinib and erlotinib as firstline treatments for patients with advanced EGFR mutationpositive non-small-cell lung cancer. Mol Clin Oncol 9(2): 201206, 2018. PMID: 30101022. DOI: 10.3892/mco.2018.1640

31 Ting J, Tien Ho P, Xiang P, Sugay A, Abdel-Sattar M and Wilson L. Cost-effectiveness and value of information of erlotinib, afatinib, and cisplatin-pemetrexed for first-line treatment of advanced EGFR mutation-positive non-small-cell lung cancer in the United States. Value Health 18(6): 774-782, 2015. PMID: 26409604. DOI: 10.1016/j.jval.2015.04.008

Received August 19, 2019

Revised September 21, 2019 Accepted September 27, 2019 